\title{
Thinking about the Teaching Secretary Work in the Second-level Colleges and Universities
}

\author{
Li Li $^{1,2}$, Bai Dong-qing ${ }^{1,2 *}$ Tan Zhao-jun ${ }^{1,2}$, Xu Hai-long ${ }^{1,2}$ \\ 1. National Demonstration Center for Experimental Aqua-ecology and Aquaculture Education (Tianjin Agriculture University) \\ Tianjin 300384 \\ 2. Department of Fishery Sciences, Tianjin Agricultural University, Tianjin 300384
}

\begin{abstract}
As the low-level manager for colleges and universities, teaching secretary plays a role of bridge and a hub for coordination and information transmission. This article analyzes the role of teaching secretary in the teaching management of second-level colleges and universities from the aspects of daily teaching management, serving teachers and students, and leaders' assistants. Meanwhile, this paper discussed the problems encountered in the work of teaching secretary from three aspects, including heavy task of teaching secretary, difficult title promotion, and deficient external training, and put forward measures and suggestions for reinforcing team construction of teaching secretary.
\end{abstract}

Keywords-Second-level colleges and universities; Teaching secretary; Teaching management

\section{INTRODUCTION}

Along with the constant expansion of enrollment scale, the trend of teaching management work becomes increasingly complicated, and the teaching management emphasis for various colleges and universities gradually shifts down, and forms three-level teaching management mode of school, second-level colleges and universities, and department, and the second-level colleges and universities have become a comprehensive unit that integrates teaching, management and scientific research. In teaching management, the function of second-level colleges and universities is similar to "small office of academic affairs" in schools, and it bears all work related to the teaching management of the entire colleges and universities. The teaching secretary in second-level colleges and universities is exactly the most basic teaching management personnel, and they are not only the executors of teaching work in colleges and universities, but also the operators of daily teaching operation, and also the server providing service for teaching, teachers and students, and they can play the role of bridge and hub for superior and subordinate coordination and information transmission. In the eyes of some teachers, the post of teaching secretary is insignificant, and they hold that they are only teaching assistant personnel doing chores, and are not as bright as the first-line teachers, but the working efficiency, the management capacity and service level of the teaching secretary can exert an important role in carrying out comprehensive teaching work, promoting various inspection evaluations, students' information feedback, etc.

\section{Function Of TeACHING SECRETARy In The TEACHING MANAGEMENT OF SECOND-LEVEL COLLEGES AND UNIVERSITIES}

The teaching management work of a school can directly influence whether the teaching activities in colleges and universities can be normally carried out, and the teaching secretary in second-level colleges and universities is an important component of teaching management in schools. They are not only responsible for formulating the class opening plan of various specialties in colleges and universities, the distribution of teaching task, textbook booking, class schedule arrangement, teachers' workload accounting and other daily teaching management work, but also assist the directors of colleges and universities in the various kinds of internship preparation and management work of the teaching field, conduct well graduation thesis defense, graduate qualification audit and other relevant teaching management work. Meanwhile, conduct well the information transmission work of the office of academic affairs and other functional departments, and they are the bridge and hub for the colleges and universities as well as various departments.

\section{A. Conduct well the daily teaching work of colleges and universities}

If we regard one semester as a straight line, the daily teaching management work can be averagely divided into three parts, i.e., the beginning of the semester, the middle of the semester, and the end of the semester [1]. The teaching secretary in colleges and universities should have respective emphasis on the management of each part, for instance, at the beginning of the semester, we emphasize on ensuring the good operation of teaching order, and meanwhile, conducting well the work about the course retaking application of students, the work about graduate supplementary examination, the work about the supplementary examination of students in schools, the work about the students' conversion of specialties; at the middle of the semester, in combination with the middle-term teaching inspection arranged by schools, we will organize the supervision of colleges and universities and check the overall teaching work therein, including the inspection of teaching archive documents, the teaching conditions of young teachers, especially newly appointed teachers, organize students' panel discussion to collect students' information feedback; at the end of the semester, conduct well all work related to examination, 
conduct well registration filling for projects examined in advance and arrange examination supervision teachers, supervise teachers to input performance on line, conduct well performance affirmation work, and then at the end of the year, conduct well the teaching performance checking work of the year, etc. meanwhile, organize students to sign up for specialized optional courses in the next semester, and arrange the class schedule of teachers in colleges and universities in the next semester, etc. during the Spring semester, it is also requested to conduct well the organization of graduation thesis defense as well as the graduation qualification audit work for graduates; we can say that, during these three periods, they basically have lots of work to do in each week, and should also cope with various emergency affairs.

\section{B. Be a good assistant to the competent teaching leader}

The Key Points for the Teaching Management in Institutions of Higher Learning issued by the Ministry of Education used to point out that: teaching secretary is engaged in handling daily teaching administrative work under the lead of the director (president) of the teaching department. This is to say that teaching secretary is engaged in completing the daily teaching management work under the lead of the directors of the department [2]. For instance, in the execution process of teaching plan and the fabrication process of cultivation scheme, it is applicable to provide reference opinions for the formulation of teaching cultivation scheme as per their own experience in specific teaching affairs and the degree of understanding for the industrial development trend of the specialty, and be a good adviser and assistant to the leaders. Besides, in the daily teaching work, it is also requested to timely remind the competent leaders for teaching of the work that should be done, such as participating in teaching work conference, attending lectures as leaders and other relevant affairs.

\section{Conduct well the service work for teachers and students}

The main role played by teaching secretary in the post of teaching management work is to serve teachers and students like a "server", and both the teachers and students will inquire the teaching secretary when there are problems in daily teaching operation management, teaching organization management, examination management, teaching archive management, etc., and the teaching secretary should patiently solve these problems one by one, and for those that cannot be solved, they should also give feedbacks to the competent leaders considering the problems and suggestions, so they can exert the function of bridge and hub for leaders, teachers and students

With respect to the aspect of teachers, get familiar with and master the various problems that may be encountered in daily teaching management, effective solve problems such as classroom conflicts, the temporary class switching of teachers, score registration errors, the completion of teachers' textbook booking, and try their best to provide service to teachers, and better improve the teaching quality. Meanwhile, actively listen to the feedbacks of teachers considering the classroom resources, students' attendance, classroom disciplines and other conditions, and give these feedbacks to the competent leaders, so as to better perfect the daily teaching management work.

With respect to the aspect of students, provide guidance and help specific to the problems encountered by students in the use of educational management system, course selection, and course retaking application, especially in student status management, during graduation audit, this will involve whether the students can normally graduate, which requires more carefulness. When students cannot graduate normally, actively contact with them to prepare for post-graduation supplementary examination work, conduct well psychological counseling, establish network exchange platform with students, fully utilize student teaching evaluation system or WeChat group and QQ group, and timely give feedbacks considering the existing problems.

\section{PROBLEMS ENCOUNTERED IN THE TEACHING SECRETARY Work In SECOND-LEVEl COLLEGES AND UNIVERSITIES}

\section{A. Heavy work task and big pressure for teaching secretary}

The teaching secretary has relatively tedious task, and as for personnel allocation, each college and university will be equipped with 2 teaching secretaries at most, but they need to bear lots of work affairs from the execution of teaching plan to the daily class switching, and all of these should be personally completed, and they are afraid that their small mistakes can cause teaching accident, so they are mostly in highly tense spirits [3]. Moreover, since the post of teaching secretary cannot obtain enough emphasis in schools, people will merely think that teachers standing on the platform are the model for imparting knowledge and educating people, while teaching managers are merely served as a prop, without knowing that most students' problems are communicated and coordinated by teaching secretaries, so this has caused the imbalance between the endeavors made by teaching secretaries and the returns obtained thereby, so they lack in work impetus.

\section{B. Big title promotion difficulty}

As a teaching secretary in second-level colleges and universities, the promotion of professional technical title is the education management research series, and is quite demanding for publishing thesis and scientific research projects. Taking our school as an example, it is requested that, during the promotion of middle level towards subtropical high title, there shall be at least two Chinese core journals being published considering the thesis aspect, and as for the scientific research aspect, it is requested to preside over and complete bureau level and above teaching research project and obtain bureau level above teaching achievement award, so as to meet the standard for participating in rating. However, teaching secretaries are faced with simple and multifarious work, so it is very hard to make scientific evaluation, and the work difficulty is big; besides, due to the multifarious work of teaching secretaries, it is also very difficult to write high-level thesis. Moreover, the high-level title index is quite tense, and our school merely has one high-level index for education management research series per year, so there is also big difficulty in title promotion. Currently, the post of enrolled teaching secretaries in our 
school is free of personnel with sub-senior above titles, and the original teaching secretaries will be converted to other posts after obtaining the sub-senior title, so the instability for the post of teaching secretary has also caused the low work enthusiasm of the entire teaching secretary team.

\section{Deficient external training and exercise opportunities for teaching secretary}

Teaching secretaries lack in opportunities to practice and exercise, and schools don't have corresponding system for encouragement; besides, in view of the particularity of teaching secretary work, teaching secretaries are busy doing multifarious affairs, and are not allowed to study for a long term outside for charging [4]. Along with the modernized management being constantly deepened, paperless office has been increasingly promoted, and the teaching management means have also been constantly improved, so it is requested that the teaching secretary should skillfully use various software systems, such as the currently used academic affair management system, graduation thesis management system, internship management system, and college students' innovation and entrepreneurship project management systems, etc. in our school; the teaching secretaries should constantly enrich their own education theoretical knowledge, constantly improve the comprehensive business capacity, provide better service for teachers and students, and improve work efficiency.

\section{MEASURES For REINFORCING THE TEAM CONSTRUCTION OF TEACHING SECRETARY}

\section{A. Innovate teaching management concept, and improve ideological understanding}

The working capacity of teaching secretary will directly influence the level of entire teaching management, and can also promote and improve the overall teaching quality to a certain extent, and make a big contribution to maintaining the normal teaching work order of schools, and improving the teaching management in schools [5]. Thus, leaders in colleges and universities should pay attention to the team construction of teaching secretary, promote the professional development of teaching secretary team, and let personnel more stable in the post. Meanwhile, the teaching secretary should correct his own working altitude, constantly update the teaching management concept, and constantly study the teaching management related theoretical knowledge and apply in practice, passionate in work, work down-to-earth, and keep improving; only by doing so can the overall team construction of teaching secretary be promoted better services be provided to teachers and students, and the constant development of teaching work in schools be promoted.

\section{B. Establish exclusive management system for teaching secretary}

The school or office of academic affairs should formulate work standard for the post of teaching secretary, further perfect the post responsibilities of teaching secretary, define specific division of work, reinforce the service awareness and management awareness of teaching secretary, search for the sense of belonging in work, and promote the ordered and highefficient completion of overall teaching work in schools. Meanwhile, establish special management system for teaching secretary, such as incentive system, evaluation system, and promotion system, especially for providing suggestions for schools in granting preferential policy in title promotion, for instance, schools can annually allocate fixed assets in setting special teaching reform research project for teaching secretary, and let each teaching secretary have their own work to do, and also have energy to publish high-level papers, mobilize the working enthusiasm of teaching secretary, and reinforce the attraction of the post. Besides, the suggestion for the office of academic affairs it to use performance evaluation to stimulate the working enthusiasm of teaching secretary on the basis of sticking to fairness and equality, construct a set of scientific and executive performance management system, and meanwhile, formulate award and punishment system, and for teaching secretaries who are derelict of duty and dilatory, punishment should be implemented, and award should be implemented for those working carefully and responsibly, build more harmonious work environment, and better mobilize the initiative motivation for the teaching secretary in work, and provide better service for teachers and students.

\section{Conduct well periodic training, and promote business capacity}

Regardless of training or further education and even selfstudy, the teaching secretary in second-level colleges and universities is aimed to improve the comprehensive capacity thereof, especially the knowledge about learning management; it combines the modern management concept and the post work thereof, so it is hoped that the school leaders can include the team construction of teaching secretary into the teacher training plan of schools, periodically provide training for teaching secretary, and also carry out communication activities for teaching secretary, let us have opportunities to accept education training, establish teaching secretary training evaluation mechanism, constantly improve the comprehensive business capacity, and improve the overall quality and work efficiency.

Meanwhile, since the teaching secretary in second-level colleges and universities is also the executor and server for information transmission, it is requested to timely master the dynamic conditions of teaching work, timely give feedback to the department head considering the hot issues reflected by teachers and students, thus the improvement of individuals' oral expressiveness and communication coordination capacity is very important, so it is hoped that the school can appoint teaching secretary to participate in professional training, to broaden horizons and conduct the post work better. 


\section{CONCLUSION}

The teaching secretary in second-level colleges and universities is the most basic manager and executer for the teaching management work of schools, and also the bridge and hub for information transmission among the educational administrative department and the leaders in colleges and universities as well as teachers and students; the working efficiency will directly influence the colleges and universities and even the operation of teaching order in schools. The problems in the team construction of teaching secretary cannot be neglected, and colleges and universities, especially the leaders of the office of academic affairs should adopt measures in combination with the actual conditions of problems, solve the development dilemma of teaching secretary, let the teaching secretary play a better role, strive to improve the teaching management level in second-level colleges and universities, and promote the entire teaching management level of schools.

\section{ACKNOWLEDGEMENT}

Fund Project: National Demonstration Center for Experimental Aqua-ecology and Aquaculture Education (Tianjin Agriculture University) Teaching Reform Project: Innovation and Practice of Experimental Teaching Quality Monitoring (Project No.: 2017GSFZXZ001)

About the Author: Li Li (1981- ), female, born in Tianjin City, Assistant Researcher, Master, and is mainly engaged in higher education teaching research and management work. Email: tjnxyshch@126.com

*Corresponding Author: Dongqing Bai (1970-), female, born in Tangshan of Hebei, Professor, Doctor, Master Tutor, and Vice President, and is mainly engaged in the higher education teaching research and scientific research work.

\section{REFERENCES}

[1] Li Li, and Xiuting Qiao. My Opinions for the Work of Teaching Secretary [J]; Journal of Tianjin Agricultural College, 2007 (Supplemented): 74-75.

[2] Yanmei Guo. Discussion about the Function of the Teaching Secretary of Second-level Colleges and Universities in College Teaching Management [J]; Southern Journal, 2012 (6): 107-109.

[3] Ying Guo. New Thinking about the Teaching Secretary Work in the Second-level Colleges and Universities [J]; Journal of Heihe University, 2016 (5): 39-40.

[4] Lina Yuan. Teaching Secretary [J]. International Conference on Education Reform and Management Innovation, 2012 (12): 278-281.

[5] Yan Ma, Liping Zheng, Shuanglin Jiang et al. On Teaching Secretary's Positive Effect in Graduation Thesis Administration [J]. Advances in Information Technology and Education, 2011 (7): 155-159. 